\title{
The effect of probiotic strains of lactic acid bacteria and bifidobacteria on the Th1 and Th2 type cytokines production in intravaginal staphylococcosis in mice
}

\author{
L.M. Lazarenko ${ }^{1}$, L.P. Babenko ${ }^{1}$, M.Yu. Hryhorash ${ }^{1}$, V.V. Mokrozub ${ }^{1}$, \\ O.M. Demchenko ${ }^{1}$, L.M. Sichel ${ }^{1,2}$, M.Ya. Spivak ${ }^{1,3}$ \\ ${ }^{1}$ D.K. Zabolotny Institute of microbiology and virology, National Academy of Sciences of Ukraine, Kyiv; \\ ${ }^{2}$ Pure Research Products, LLC, Colorado, USA; \\ ${ }^{3}$ LLC "Diaprof", Ukraine; e-mail: LazarenkoLM@gmail.com
}

\begin{abstract}
The probiotic strains of Lactobacillus casei IMV B-7280, Bifidobacterium animalis VKL, B. animalis VKB (individually) or L. casei IMV B-7280 - B. animalis VKB - B. animalis VKL composition balanced the Th1/Th2 cytokines production at normal condition and in the cases of experimental intravaginal staphylococcosis in $B A L B / c$ mice in different periods of observation. L. casei IMV B-7280 and B. animalis VKB (individually) at normal condition increased the Th1 type cytokines interleukin (IL)-12 and interferon (IFN)- $\gamma$ production. Instead, B. animalis VKL after injection into intact mice did not affect the IL-12 production but slightly increased the IFN- $\gamma$ production. In the cases of experimental intravaginal staphylococcosis in mice the balancing of Th1/Th2 immune response under the influence of L. casei IMV B-7280 is due to increased production of IL-12 and IFN- $\gamma$, as well as decreased Th2 type cytokine IL-4 production. The IL-12 and IFN- $\gamma$ production in staphylococcus-infected mice that received B. animalis VKL or B. animalis VKB (individually) was increased, but these probiotic bacteria had no significant effect on IL-4 production. Under the influence of L. casei IMV B-7280, B. animalis VKB, B. animalis VKL (individually) in the cases of experimental intravaginal staphylococcosis in mice the IL-4/IFN- $\gamma$ ratio was significantly decreased. The shift from Th2 to Th1 type cytokines production was also observed in staphylococcus-infected mice that received L. casei IMV B-7280 - B. animalis VKB - B. animalis VKL composition. The IL-12 and IFN- $\gamma$ production was increased, instead, $I L-4$ production as well as $I L-4 / I F N-\gamma$ ratio were decreased in mice that received this probiotic composition in different periods of observation.So, L. casei IMV B-7280, B. animalis VKB and B. animalis VKL (individually) and L. casei IMV B-7280 - B. animalis VKB - B. animalis VKL composition are promising to create highly effective immunobiotics with immunomodulatory effect that are able to balance Th1/Th2 type of immunity by shifting the cytokine profile with decreased the IL-4/IFN- $\gamma$ ratio. Key words: lactic acid bacteria; bifidobacteria; mice; intravaginal staphylococcosis; cytokines.
\end{abstract}

\section{INTRODUCTION}

The appearance of atypical forms of pathogens and pathogens with resistance to a wide range of antibiotics and other antibacterial drugs as a result of often unjustified use of them has determined the requirement of new highly effective methods of antibacterial therapy of patients with infectious and inflammatory diseases, including urinary tract infections. Lactic acid bacteria (LAB) and bifidobacteria that belong to the groups of microorganisms most frequently uses as probiotics due to their competitive inhibition of pathogenic bacteria colonization in the intestinal and urinary tracts; their ability to colonize the mucosal epithelial cells as well as their beneficial effects on the gut immune system can be used in complex therapy of patients with infectious diseases of urinary tract and other pathologies $[1,2,3.4,5]$.

It has been established that an important mechanisms of immunomodulatory effect of many probiotic strains of LAB and bifidobacteria are the induction of regulatory cytokines

(C) Lazarenko L.M., Babenko L.P., Hryhorash M.Yu., Mokrozub V.V., Demchenko O.M., Sichel L.M., Spivak M.Ya. 
via the Toll-like receptor (TLR) pathway $[6,7$, $8,9,10,11]$, modulation of antigen presenting cells [11], induction of $\mathrm{T}$ regulatory cells [12, $13,14]$, and influence on development and functions of epithelial cells [15]. Effect of probiotic bacteria on the production of Th1 (interleukin (IL)-2, IL-12, interferon (IFN)- $\gamma$ etc.) and Th2 (IL-4, IL-5, IL-9 etc.) type cytokines, balancing of Th1/Th2 immune response and, as a result, determining the development of cellular or humoral immunity respectively play an important role in effective immune response ensuring in many pathological conditions. It should be noted that the Th1 and Th2 type cytokines production by immune cells in response to the effect of LAB and bifidobacteria is strain- and dose-dependent $[9,16,17,18,19]$ and the level of IL-12 production is critical for determining the direction of the Th1 type immune response in mice, but the Th1 type immunity in the human depends on the IL-12 as well as IFN- $\gamma$ production [20]. So, various strains of LAB and bifidobacteria can differently influence the production of Th1 or/ and Th2 type cytokines; therefore this feature should be taken into account when creating a probiotics. Perhaps there are also differences in immunomodulatory effect of probiotic bacteria under normal and various pathological conditions. Therefore, in the selection of LAB and bifibobacteria strains for probiotics creation it is necessary to evaluate their immunomodulatory effect with obligatory definition of their influence on cytokines production simultaneously in various experimental and clinical studies.

Early we have screened our collection of LAB and bifidobacteria for their efficacy in modulating host immune response at normal condition and in the cases of experimental staphylococcosis in BALB/c mice. It was established that probiotic bacteria Lactobacillus casei IMV B-7280, Bifidobacterium animalis VKB and $B$. animalis VKL are promising for the creation of immunobiotics with antibacterial and immunomodulatory effects. Increase the functional activity of phagocytes and production of IFN in intact mice under the influence of these probiotic bacteria were observed [21]. L. casei IMV B-7280, $B$. animalis VKB and B. animalis VKL (individually) or L. casei IMV B-7280 - B. animalis VKB $B$. animalis VKL composition were able to inhibit Staphylococcus aureus growth in the vagina and influence the cellular immune response in the case of the experimental intravaginal staphylococcosis in BALB/c mice. These probiotic bacteria and probiotic composition normalized the CD4+/CD8+ ratio in staphylococcus-infected mice compared with infected mice that did not receive probiotic bacteria. An increase in the number of CD19+ B-lymphocytes in the spleens of these mice was also detected [22].

So, the aim of this work was to study the comparative effect of $L$. casei IMV B-7280, $B$. animalis VKB and $B$. animalis VKL (individually) or L. casei IMV B-7280 - B. animalis VKB - B. animalis VKL composition on the Th1 and Th2 type cytokines production in the case of the experimental intravaginal staphylococcosis in mice as well as under normal condition.

\section{METHODS}

Experimental studies were performed on sixweek-old female BALB/c mice, synchronized in their estral cycle. Mice were kept in standard vivarium conditions at a temperature of $22 \pm 1$ ${ }^{\circ} \mathrm{C}$, they were provided with the full mixed feed and had free access to automatic water bowls.

This study was carried out in strict accordance with the rules established by the Law of Ukraine № 3447-IV “On protection of animals from cruelty" and "European Convention for the Protection of vertebrate animals used for experimental and scientific purposes from 09.20.1985" (Strasbourg, 1986) and in accordance with the "General ethical animal experimentation" (First National Congress on bioethics, 2001). All surgery was performed under anesthesia, and all efforts were made to minimize suffering.

L. casei IMV B-7280, B. animalis VKL and $B$. animalis $\mathrm{VKB}$ from our collection of $\mathrm{LAB}$ and bifidobacteria were previously selected by us from gut content of healthy people and deposited 
in the Ukrainian collection of microorganisms (D.K. Zabolotny Institute of Microbiology and Virology, NAS of Ukraine, Ukraine). The studies were performed using bacteria lyophilized in Cuddon Freeze Dryer FD1500 (New Zealand). Before each experiment the viability of the probiotic bacteria was tested by monitoring their growth on the Man-Rogosa-Sharpe (MRS) agar medium or Bifidum-agar at $37^{\circ} \mathrm{C}$ for $24-48 \mathrm{~h}$. Staphylococcus aureus strain 8325-4 (kindly provided to us by Professor V.S. Zuyeva, N.F. Gamaleya Institute of Epidemiology and Microbiology, Russian Federation) was grown on selective agar medium for staphylococci (BAIRD-PARKERAgar, Merck, Germany), which contained gentamicin at a concentration of $15 \mathrm{mg} / \mathrm{ml}$, at $37^{\circ} \mathrm{C}$ for $24 \mathrm{~h}$. This strain had plasmid-based resistance to gentamicin, allowing it to be separated from other vaginal Staphylococcus strains.

Staphylococcosis was modelled through single intravaginal administration of $S$. aureus strain 8325-4 daily culture to mice, in dose of $25 \mathrm{mcl}$ of phosphate buffered saline (PBS) in the amount of $5 \times 10^{7}$ cells per animal. The following clinical manifestations of the infection process were observed in the infected mice: significant increase of whitish mucous secretions of the vagina, elevation of body temperature, inactivity, and loss of appetite.

One day after infection with $S$. aureus strain 8325-4 mice were given an intravaginal injection of lyophilized L. casei IMV B-7280, B. animalis VKL, B. animalis VKB (individually) or L. casei IMV B-7280 - B. animalis VKB - B. animalis VKL composition in dose of $25 \mathrm{mcl}$ of PBS in the amount of $1 \times 10^{6}$ cells per animal, once a day for 7 days. When three strains of proboitic bacteria were used as a composition, they were used at the concentration to reach this total amount of bacterial cells. L. casei IMV B-7280, B. animalis VKL, B. animalis VKB (individually) were also injected into the vagina of non infected (intact) mice using the same scheme. Two separate groups of comparison included staphylococcus-infected and intact mice, which did not receive probiotic strains, but received $25 \mathrm{mcl}$ of PBS into vagina.
$\mathrm{BALB} / \mathrm{c}$ mice were divided into 6 experimental groups (10 mice in each): 1) intact mice; 2) intact mice that received L. casei IMV B-7280; 3 ) intact mice that received $B$. animalis VKB; 4 ) intact mice that received $B$. animalis VKL; 5) control mice, infected with $S$. aureus 8325-4; 6) staphylococcus-infected mice that received L. casei IMV B-7280; 7) staphylococcusinfected mice that received $B$. animalis $\mathrm{VKB}$; 8) staphylococcus-infected mice that received B. animalis VKL; 6) staphylococcus-infected mice that received $L$. casei IMV B-7280 - B. animalis VKL - B. animalis VKB composition.

On the $1^{\text {st }}, 3^{\text {rd }}$ and $6^{\text {th }}$ days after probiotic bacteria or probiotic composition injection, peripheral blood were taken from the tail vein of each mouse of all groups. Blood serum samples were kept at $-40{ }^{\circ} \mathrm{C}$ during one month. In the blood serum samples the concentration of IL12 , IFN- $\gamma$ and IL-4 was determined by ELISA according to the manufacturer's instructions (Bender MedSystems GmbH Campus Vienna Biocenter 2 A-1030, Austria).

All received digital data were processed with the help of the Epi Info software (version 6.0) through analysis of variance. Numerical data were represented as arithmetic average and standard error. The null hypothesis for the control and experimental comparative groups was checked using Wilcoxon-Mann-Whitney (U) criterion. The differences between the groups were considered statistically meaningful at $P<0.05$.

\section{RESULTS AND DISCUSSION}

Analysis of serum cytokines showed an increase level of Th1 type cytokines IL-12 and IFN- $\gamma$ after injection of L. casei IMV B-7280 or B. animalis VKB (individually) into intact mice in different periods of observation (Table 1).

The IL-12 and IFN- $\gamma$ levels in serum were increased on the $3^{\text {rd }}$ and $6^{\text {th }}$ days under influence of $L$. casei IMV B-7280. Intact mice that received $B$. animalis $\mathrm{VKB}$ had higher IL-12 level on the $1^{\text {st }}$ and $3^{\text {rd }}$ days. The IFN- $\gamma$ level in the serum of mice of this probiotic bacteria 
Table 1. The cytokines level in the serum of intact mice that received probiotic bacteria

\begin{tabular}{l|c|c|c|c|}
\hline \multirow{2}{*}{ Groups of mice } & Observation period & \multicolumn{3}{|c|}{ Concentration of cytokines (pg/ml) } \\
\cline { 3 - 5 } & $\begin{array}{c}\text { after injection of } \\
\text { probiotic strains }\end{array}$ & IL-12 & IFN- $\gamma$ & IL-4 \\
\hline Intact mice & - & $613.8 \pm 56.9$ & $3.7 \pm 0.5$ & $1.23 \pm 0.20$ \\
Intact mice that & 1 day & $736.0 \pm 41.6$ & $9.2 \pm 0.6^{*}$ & $1.02 \pm 0.10$ \\
received L. casei IMV & 3 day & $928.8 \pm 56.6^{*}$ & $4.3 \pm 0.9$ & $1.96 \pm 0.09$ \\
B-7280 & 6 day & $904.4 \pm 66.3^{*}$ & $7.0 \pm 0.7^{*}$ & $0.98 \pm 0.02$ \\
Intact mice that & 1 day & $811.8 \pm 52.5^{*}$ & $14.7 \pm 1.0^{*}$ & $1.43 \pm 0.48$ \\
received B. animalis & 3 day & $831.4 \pm 46.5^{*}$ & $19.3 \pm 2.7^{*}$ & $1.59 \pm 0.31$ \\
VKB & 6 day & $526.4 \pm 31.7$ & $18.7 \pm 1.1^{*}$ & $0.46 \pm 0.08^{*}$ \\
Intact mice that & 1 day & $439.0 \pm 94.8$ & $7.0 \pm 0.2$ & $1.39 \pm 0.43$ \\
received B. animalis & 3 day & $542.3 \pm 23.8$ & $5.7 \pm 0.3$ & $1.21 \pm 0.12$ \\
VKL & 6 day & $482.0 \pm 68.7$ & $5.6 \pm 0.9$ & $0.70 \pm 0.20$ \\
\hline
\end{tabular}

Significant difference with the intact mice is represented by $*(P<0.05)$.

group was increased throughout the observation period. Thus, $B$. animalis VKB more effectively enhanced the IFN- $\gamma$ production in intact mice than L. casei IMV B-7280. Instead, B. animalis VKL did not affect the IL-12 production in intact mice (Table 1). However, treatment with these probiotic bacteria resulted in slightly increasing of the IFN- $\gamma$ level in serum of intact mice on the $1^{\text {st }}$ day.

As shown in Table 1, L. casei IMV B-7280 or $B$. animalis VKL (individually) did not affect the production of Th2 type cytokine IL-4 in intact mice. The IL-4 level in serum of intact mice after $B$. animalis VKB injection also did not change on the $1^{\text {st }}$ and $3^{\text {rd }}$ days, but on the $6^{\text {th }}$ day was slightly decreased.

At the same time, we have found that the IL-12 and IFN- $\gamma$ as well as IL-4 production after injection of $L$. casei IMV B-7280, B. animalis VKL or $B$. animalis VKB (individually) into staphylococcus-infected mice was different than in intact mice (Table 2). It should be noted that the IL-12 level in the serum of staphylococcusinfected mice that did not receive the probiotic bacteria (control group) was decreased but the IL-4 level was increased on the $1^{\text {st }}$ day compared with intact mice. Also, the tendency to decrease of the IFN- $\gamma$ production in these mice was detected throughout the observation period.
The IL-12 level in serum of staphylococcusinfected mice after injection of $L$. casei IMV B-7280 or B. animalis VKL (individually) was increased on the $1^{\text {st }}$ and $6^{\text {th }}$ days compared with control group. Staphylococcus-infected mice that received $B$. animalis $\mathrm{VKB}$ had higher IL12 level in serum throughout the observation period. As shown in Table 2, the IFN- $\gamma$ level in serum of staphylococcus-infected mice in different periods of observation after injection of L. case $i \mathrm{IMV}$ B-7280 (on the $1^{\text {st }}$ and $3^{\mathrm{dr}}$ days) or $B$. animalis $\mathrm{VKB}$ (on the $1^{\text {st }}$ and $6^{\text {th }}$ days), or $B$. animalis VKL (on the $3^{\text {rd }}$ and $6^{\text {th }}$ days) was also increased compared with control group. The IL-12 and IFN- $\gamma$ level in serum of mice of these three probiotic bacteria groups in most cases was even increased compared with intact mice.

Under the influence of $L$. casei IMV B-7280 the IL-4 level in serum of staphylococcus-infected mice was decreased on the $1^{\text {st }}$ day compared with control group. Also, the tendency to decrease of IL-4 level in serum of staphylococcusinfected mice that received $B$. animalis $\mathrm{VKB}$ or $B$. animalis VKL on the $1^{\text {st }}$ day was detected.

Treatment of staphylococcus-infected mice with L. casei IMV B-7280 - B. animalis VKB - B. animalis VKL composition also resulted in increasing of the IL-12 and IFN- $\gamma$ production in different periods of observation (Table 2). 
The effect of probiotic strains of lactic acid bacteria and bifidobacteria on the th1 and th2 type cytokines production

Table 2. The cytokines level in the serum of staphylococcus-infected mice that received probiotic bacteria or probiotic composition

\begin{tabular}{|c|c|c|c|c|}
\hline \multirow{2}{*}{ Groups of mice } & \multirow{2}{*}{$\begin{array}{c}\text { Observation period } \\
\text { after injection of } \\
\text { probiotic strains }\end{array}$} & \multicolumn{3}{|c|}{ Concentration of cytokines $(\mathrm{pg} / \mathrm{ml})$} \\
\hline & & IL-12 & IFN- $\gamma$ & IL-4 \\
\hline Intact mice & - & $613.8 \pm 56.9$ & $3.7 \pm 0.5$ & $1.23 \pm 0.20$ \\
\hline \multirow{3}{*}{$\begin{array}{l}\text { Infected mice (control } \\
\text { group) }\end{array}$} & 1 day & $346.8 \pm 19.8^{*}$ & $2.3 \pm 0.8$ & $2.04 \pm 0.01 *$ \\
\hline & 3 day & $686.2 \pm 41.0$ & $2.5 \pm 0.9$ & $1.19 \pm 0.12$ \\
\hline & 6 day & $598.3 \pm 53.3$ & $2.4 \pm 0.1$ & $1.09 \pm 0.34$ \\
\hline Infected mice that & 1 day & $615.0 \pm 15.8^{\bullet}$ & $14.5 \pm 1.9^{\bullet *}$ & $1.03 \pm 0.05^{\circ}$ \\
\hline received $L$. casei IMV & 3 day & $701.0 \pm 13.0$ & $27.9 \pm 1.8^{\bullet *}$ & $1.20 \pm 0.09$ \\
\hline B-7280 & 6 day & $831.0 \pm 45.2^{*}$ & $4.2 \pm 1.0$ & $1.39 \pm 0.76$ \\
\hline Infected mice that & 1 day & $1118.5 \pm 34.5^{\circ *}$ & $7.9 \pm 0.4^{* *}$ & $1.52 \pm 0.23$ \\
\hline received $B$. animalis & 3 day & $1317.0 \pm 26.0^{\circ *}$ & $4.7 \pm 0.1$ & $1.05 \pm 0.37$ \\
\hline VKB & 6 day & $969.0 \pm 24.9^{* *}$ & $7.0 \pm 0.8^{* *}$ & $1.88 \pm 0.76$ \\
\hline Infected mice that & 1 day & $863.3 \pm 13.9^{* *}$ & $2.5 \pm 0.8$ & $1.58 \pm 0.41$ \\
\hline received $B$. animalis & 3 day & $633.3 \pm 25.8$ & $9.4 \pm 1.0^{* *}$ & $1.24 \pm 0.56$ \\
\hline VKL & 6 day & $1003.0 \pm 19.3^{\circ *}$ & $16.5 \pm 1.8^{* *}$ & $1.45 \pm 0.09$ \\
\hline Infected mice that & 1 day & $615.0 \pm 28.0^{\circ}$ & $30.3 \pm 2.8^{* *}$ & $0.89 \pm 0.04^{\circ}$ \\
\hline received composition of & 3 day & $1378.2 \pm 89.8^{\circ *}$ & $11.5 \pm 1.9^{* *}$ & $1.23 \pm 0.31$ \\
\hline probiotic strains & 6 day & $537.2 \pm 22.6$ & $10.8 \pm 1.1^{\bullet *}$ & $1.10 \pm 0.54$ \\
\hline
\end{tabular}

Significant differences with the intact mice are represented by $*(P<0.05)$, while differences with the indicators of the staphylococcus-infected mice who did not receive probiotic strains or probiotic composition (control group) are represented by ${ }^{*}(P<0.05)$.

Staphylococcus-infected mice that received $L$. casei IMV B-7280 - B. animalis VKB - B. animalis VKL composition had higher level of IL12 in serum on the $1^{\text {st }}$ and $3^{\text {rd }}$ days but the level of IFN- $\gamma$ in serum was increased throughout the observation period compared with control group. The IL-4 level in serum of infected mice that obtained probiotic composition was decreased on the $1^{\text {st }}$ day.

The ratio of IL-4/IFN- $\gamma$ was significantly increased in the staphylococcus-infected mice on the $1^{\text {st }}$ day (Fig. 1).

On the $3^{\text {rd }}$ day, IL-4/IFN- $\gamma$ ratio was decreased, but remained slightly increased compared with intact mice $(P<0.05)$. After injection of $L$. casei IMV B-7280, B. animalis VKB, $B$. animalis VKL (individually) or L. casei IMV B-7280 - B. animalis VKB - B. animalis VKL composition into staphylococcus-infected mice the ratio of IL-4/IFN- $\gamma$ was significantly decreased compared with control group through- out the observation period. So, these results suggested that infection with $S$. aureus 8325-4 change the immune response which manifested as a shift from Th1 to Th2 type of immunity. But L. casei IMV B-7280, B. animalis VKB, $B$. animalis VKL (individually) or L. casei IMV B-7280 - B. animalis VKB - B. animalis VKL composition alter the development of immune response of staphylococcus-infected mice, which appears as a shift from Th2 to Th1 type of immunity.

We had previously shown [22] that L. casei IMV B-7280, $B$. animalis $\mathrm{VKL}$ and $B$. animalis $\mathrm{VKB}$, (individually) or $L$. casei IMV B-7280 - $B$. animalis $\mathrm{VKB}-B$. animalis $\mathrm{VKL}$ composition after intravaginal injection once a day for 7 days, effectively delayed $S$. aureus $8325-4$ growth in the vagina (during the observation period - up to 12 days) of staphylococcus-infected BALB/c mice and reduced the severity of disease. In this paper we established that the shift from Th2 to 
Th1 type cytokines production may be one of the important mechanisms of protective effect of these probiotic bacteria and probiotic composition in the cases of experimental intravaginal staphylococcosis in BALB/c mice. L. casei IMV B-7280, B. animalis VKL and B. animalis VKB (individually) shifted cytokines production from Th2 to Th1 type also at normal condition. Thus probably these probiotic bacteria can be used prophylactically to prevent infection disease but more research is needed to confirm this.

The production of Th1 type cytokines IL12 and IFN- $\gamma$ after L. casei IMV B-7280 or B. animalis VKB (individually) injection into staphylococcus-infected mice as well as intact mice was increased at different periods of observation. The correlation between the IL-12 and IFN- $\gamma$ production in mice of these two probiotic bacteria groups was found. Instead, $B$. animalis VKL increased the production of IL-12 and IFN- $\gamma$ in different periods of observation in staphylococcus-infected mice, but did not affect the IL-12 production in intact mice. Among this three probiotic strains only L. casei IMV B-7280 reduced the increased production of IL-4 after injection to staphylococcus-infected mice. The results of our studies have shown that cytokine production in response to some probiotic bacteria, such as $B$. animalis VKL, may depend on the different levels of producing cells activity in the normal state and pathology.

So, in the cases of experimental intravaginal staphylococcosis in mice the Th1/Th2 balancing under the influence of $L$. casei IMV B-7280 can be indicated in increased production of IL-12 and IFN- $\gamma$ as well as reduced production of IL-4. B. animalis VKL or B. animalis VKB in cases of intravaginal staphylococcal infection increased production of IL-12 and IFN- $\gamma$, but had no significant effect on IL-4 production. The ratio of IL-4/IFN- $\gamma$ was significantly decreased after L. casei IMV B-7280, B. animalis VKB, $B$. animalis VKL (individually) injection into staphylococcus-infected mice that confirmed a shift from Th2 to Th1 immune response.

According to the literature data, LAB strains had different effect on the Th1/Th2 balance upward of Th1 type cytokines production [23, 24, 25]. L. plantarum NCU116 after injection into immunosuppressed mice enhanced the

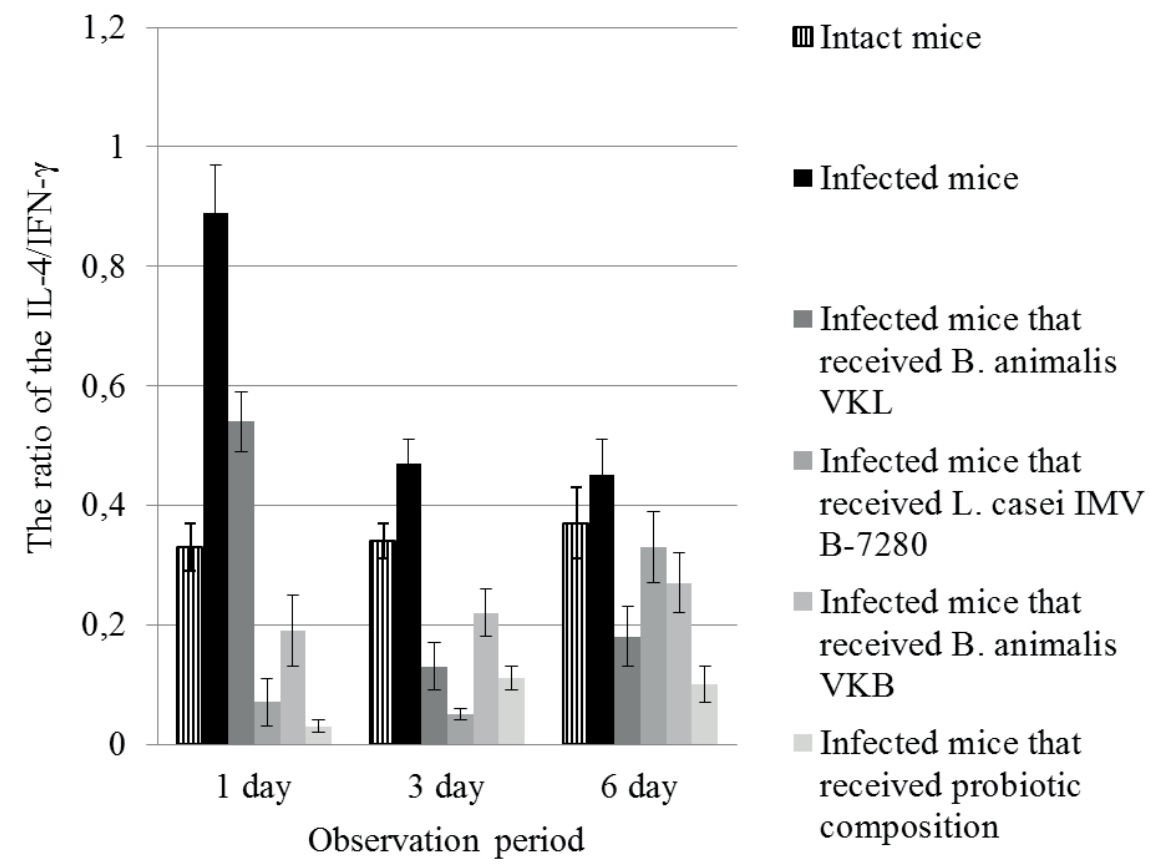

Fig. 1. The ratio of IL-4/IFN- $\gamma$ in staphylococcus-infected mice that received L. casei IMV B-7280, B. animalis VKL and B. animalis VKB, (individually) or L. casei IMV B-7280 - B. animalis VKB - B. animalis VKL composition 
level of Th1 type cytokine IL-2 gene expression and significantly reduced the level of Th2-type cytokine IL-4 in the small intestine [26]. L. rhamnosus balanced Th1/Th2 profile of splenocytes by increasing IFN- $\gamma$ and decreasing IL-4 as well as IL-10 production in aging mice that associated with enhanced resistance to $E$. coli infection [27]. Consumption of $L$. rhamnosus (MTCC: 5897 ) probiotic strain that contained in fermented milk, balanced Th1/ Th2 immune response by shifting the cytokine profile (IFN- $\gamma$, IL-4 and IL-10) with increasing of IFN- $\gamma /$ IL-4 ratio in newborn mice during the suckling-weaning transition [28]. Some of bifidobacteria strains also increase Th1-type cytokines production but other strains of bifidobacteria do not have effect on their production or increase it slightly $[17,29,30]$. Instead, $B$. animalis ssp. lactis CNCM-I2494 in the case of chronic dinitrobenzene sulfonic acid-induced low-grade inflammation model in mice balanced the $\mathrm{Th} 1 / \mathrm{Th} 2$ ratio by increasing the production of Th2 type cytokines IL-4, IL-5, and IL-10 [31]. Therefore, comprehensive studies of probiotic bacteria immunomodulatory action under various pathologies are necessary.

Some strains of LAB and bifidobacteria are able to enhance the production of IFN- $\gamma$ and IL12 and also activate the production of other proinflammatory cytokines such as TNF- $\alpha$ [9]. This property is also strain-dependent. For example, L. reuteri BM36304 had a pro-inflammatory effect that confirmed by significantly stimulated production of TNF- $\alpha$, but $L$. reuteri BM36301 was an anti-inflammatory strain [19]. L. casei IMV B-7280, B. animalis VKL and B. animalis VKB from our collection of probiotic bacteria increased the production of IFN- $\gamma$, whereas they did not affect the production of TNF- $\alpha$ in vivo [21], so it can be assumed that they will not cause the development of inflammation.

In our study the shift from Th2 to Th1 was also observed after injection of $L$. casei IMV B-7280 - B. animalis VKB - B. animalis VKL composition to staphylococcus-infected mice. The IL-12 and IFN- $\gamma$ production was increased, instead, IL-4 production as well as IL-4/IFN- $\gamma$ ratio were decreased in mice of this probiotic composition group. It should be noted, that unlike the single probiotic bacteria, L. casei IMV B-7280 - B. animalis VKB - B. animalis VKL composition in staphylococcus-infected mice caused activation of $\gamma$-interferonogenesis throughout the observation period. This probably causes the effective antistaphylococcal influence of the probiotic compositions in the cases of experimental intravaginal compared to each strain separately, as shown earlier [22].

So, L. casei IMV B-7280, B. animalis VKL or $B$. animalis VKB (individually) and L. casei IMV B-7280 - B. animalis VKB - B. animalis VKL composition are promising to create highly effective immunobiotics, that are able to balance Th1/ Th2 type of immunity by shifting the cytokine profile (IL-12, IFN- $\gamma$ and IL-4) with increased IFN- $\gamma /$ IL-4 ratio and have antibacterial effect. However, additional clinical studies should be conducted to ensure that these probiotic strains and probiotic composition could be used in treatment or prevention of infection diseases.

The authors of this study confirm that the research and publication of the results were not associated with any conflicts regarding commercial or financial relations, relations with organizations and/or individuals who may have been related to the study, and interrelations of co-authors of the article.

\section{Л.Н. Лазаренко ${ }^{1}$, Л.П. Бабенко ${ }^{1}$, М.Ю. Григораш ${ }^{1}$, В.В. Мокрозуб ${ }^{1}$, О.Н. Демченко ${ }^{1}$, Л.Н. Сишел ${ }^{1,2}$, Н.Я. Спивак ${ }^{1,3}$ \\ ВЛИЯНИЕ ПРОБИОТИЧЕСКИХ ШТАММОВ ЛАКТОБАЦИЛЛ И БИФИДОБАКТЕРИЙ НА ПРОДУКЦИЮ ЦИТОКИНОВ ТИПА ТН1 И ТН2 ПРИ ИНТРАВАГИНАЛЬНОЙ СТАФИЛОКОККОВОЙ ИНФЕКЦИИ У МЫШЕЙ}

Пробиотические штаммы Lactobacillus casei IMB B-7280, Bifidobacterium animalis VKL, B. animalis VKB (отдельно) или композиция L. casei IMB B-7280 - B. animalis VKB - B. animalis VKL балансировали продукцию цитокинов Th1/ Th2 в условиях нормы и при экспериментальной интравагинальной стафилококковой инфекции у мышей линии 
BALB/c в различные периоды наблюдения. L. casei IMB B-7280 и B. animalis VKB (отдельно) в условиях нормы увеличивали продукцию цитокинов Th1-типа - интерлейкина (ИЛ)-12 и интерферона (ИФН)- $\gamma$. Напротив B. animalis VKL после введения интактным мышам не влиял на продукцию ИЛ-12, но незначительно усиливал продукцию ИФН-ү. При экспериментальной интравагинальной стафилококковой инфекции балансирование Th1/Th2-ответа под влиянием $L$. casei IMB B-7280 происходило вследствие как повышения продукции ИЛ-12 и ИФН- $\gamma$, так и снижения продукции цитокина Th2-типа - ИЛ-4. Продукция ИЛ-12 и ИФН- $\gamma$ повышалась у инфицированных стафилококком мышей, которым вводили B. animalis VKL или B. animalis VKB (отдельно), но эти пробиотические бактерии не имели существенного влияния на продукцию цитокина ИЛ-4. Под влиянием L. casei IMB В-7280, B. animalis $\mathrm{VKB}$, B. animalis VKL (отдельно) при экспериментальной интравагинальной стафилококковой инфекции у мышей значительно уменьшалось соотношение содержание ИЛ-4/ИФН- $\gamma$. Сдвиг продукции цитокинов от типа Th2 к Th1 наблюдался также после введения инфицированным стафилококком мышам композиции L. casei IMB B-7280 - B. animalis VKB - B. animalis VKL. Продукция ИЛ-12 и ИФН- $\gamma$ увеличивалась, а ИЛ-4 и соотношение содержания ИЛ-4/ИФН- $\gamma$, наоборот, снижались в разные периоды наблюдения в группе мышей, получавших эту пробиотическую композицию. Таким образом, L. casei IMB B-7280, B. animalis VKB, B. animalis VKL (отдельно) и композиция L. casei IMB B-7280 - B. animalis VKB - B. animalis VKL являются перспективными для создания высокоэффективных иммунобиотиков с иммуномодулирующим действием, которые способны балансировать Th1/ Th2-иммунный ответ, изменяя цитокиновый профиль со снижением соотношения ИЛ-4/ ИФН- $\gamma$.

Ключевые слова: лактобациллы; бифидобактерии; мыши; интравагинальная стафилококовая инфекция; цитокины.

\section{Л.М. Лазаренко ${ }^{1}$, Л.П. Бабенко ${ }^{1}$, М.Ю. Григораш ${ }^{1}$, В.В. Мокрозуб, О.М. Демченко ${ }^{1}$, Л.М. Сішел ${ }^{1,2}$, М.Я. Співак ${ }^{1,3}$ \\ ВПЛИВ ПРОБІОТИЧНИХ ШТАМІВ ЛАК- ТОБАЦИЛ І БІФІДОБАКТЕРІЙ НА ПРО- ДУКЦІЮ ЦИТОКІНІВ ТИПУ ТН1 ТА ТН2 ЗА ІНТРАВАГІНАЛЬНОЇ СТАФІЛОКОКО- ВОЇ ІНФЕКЦІЇ У МИШЕЙ}

Пробіотичні штами Lactobacillus casei IMB B-7280, Bifidobacterium animalis VKL, B. animalis VKB (окремо) або композиція $L$. casei IMB B-7280 - B. animalis VKB B. animalis VKL балансували продукцію цитокінів Th1/ Th2 у нормі та за експериментальної інтравагінальної стафілококової інфекції у мишей лінії $\mathrm{BALB} / \mathrm{c}$ у різні періоди спостереження. L. casei IMB B-7280 і B. animalis VKB (окремо) в нормі підвищували продукцію цитокінів Th1 типу - інтерлейкіну (ІЛ) - 12 та інтерферону (ІФН)- $\gamma$.
Навпаки B. animalis VKL після введення інтактним мишам не впливав на продукцію ІЛ-12, але незначно посилював продукцію ІФН- $\gamma$. За експериментальної інтравагінальної стафілококової інфекції у мишей балансування Th1/Th2відповіді під впливом L. casei IMB В-7280 відбувалося внаслідок як підвищення продукції ІЛ-12 і ІФН- $\gamma$, так і зниження продукції цитокіну Th2-типу - IЛ-4. Продукція ІЛ-12 і ІФН- $\gamma$ підвищувалась в інфікованих стафілококом мишей, яким вводили $B$. animalis VKL або B. animalis VKB (окремо), але ці пробіотичні бактерії не мали суттєвого впливу на продукцію ІЛ-4. Під впливом L. casei IMB B-7280, B. animalis VKB, B. animalis VKL (окремо) за експериментальної інтравагінальної стафілококової інфекції у мишей значно зменшувалося співвідношення вмісту ІЛ-4/ІФН- $\gamma$. Зрушення продукції цитокінів від типу Th2 до Th1 спостерігалося також після введення інфікованим стафілококом мишам композиції L. casei IMB B-7280 - B. animalis VKB - B. animalis VKL. Продукція ІЛ-12 і ІФН- $\gamma$ збільшувалася, а ІЛ-4 та співвідношення вмісту ІЛ-4/ІФН- $\gamma$, навпаки, знижувались у різні періоди спостереження в групі інфікованих стафілококом мишей, які отримували цю пробіотичну композицію. Таким чином, L. casei IMB B-7280, B. animalis VKB, B. animalis VKL (окремо) і композиція L. casei IMB B-7280 - B. animalis $\mathrm{VKB}$ - B. animalis VKL $€$ перспективними для створення високоефективних імунобіотиків з імуномодулювальною дією, які здатні балансувати Th1/Th2 імунну відповідь, змінюючи цитокіновий профіль зі зниженням співвідношення ІЛ-4/ІФН- $\gamma$.

Ключові слова: лактобацили; біфідобактерії; миші; інтравагінальна стафілококова інфекція; цитокіни.

${ }^{1}$ Інститут мікробіології і вірусологї ім. Д.К. Заболотного НАН України, Украӥна, Київ;

${ }^{2}$ TOB “Pure Research Products”, Колорадо, США;

${ }^{3}$ TOB “Дianpoф”; e-mail: LazarenkoLM@gmail.com

\section{REFERENCES}

1. Bruce AW, Reid G. Intravaginal instillation of lactobacilli for prevention of recurrent urinary tract infections. Can J Microbiol. 1988 Mar; 34(3):339-43.

2. Delia A, Morgante G, Rago G, Musacchio MC, Petraglia F, De Leo V. Effectiveness of oral administration of Lactobacillus paracasei subsp. paracasei $\mathrm{F} 19$ in association with vaginal suppositories of Lactobacillus acidofilus in the treatment of vaginosis and in the prevention of recurrent vaginitis. Minerva Ginecol. 2006 Jun; 58(3): 227-31.

3. Drago L, De Vecchi E, Nicola L, Zucchetti E, Gismondo MR, Vicariotto F. Activity of a Lactobacillus acidophilusbased douche for the treatment of bacterial vaginosis. J Altern Complement Med. 2007 May; 13 (14): 435-8.

4. Falagas ME, Betsi GI, Athanasiou S. Probiotics for the treatment of women with bacterial vaginosis. Clin Microbiol Infect. 2007; Jul;13(7): 657-64.

5. Amdekar S, Singh V, Singh DD. Probiotic therapy: immunomodulating approach toward urinary tract infection. 
The effect of probiotic strains of lactic acid bacteria and bifidobacteria on the th 1 and th 2 type cytokines production

Curr Microbiol. 2011 Nov; 63(5): 484-90.

6. Christensen HR, Frøkiaer H, Pestka JJ. Lactobacilli differentially modulate expression of cytokines and maturation surface markers in murine dendritic cells. J Immunol. 2002 Jan; 168(1): 171-8.

7. Iwabuchi N, Takahashi N, Xiao JZ, Miyaji K, Iwatsuki K. In vitro Th1 cytokine-independent Th2 suppressive effects of bifidobacteria. Microbiol Immunol. 2007; 51(7): 649-60.

8. Gad M, Ravn P, Søborg DA, Lund-Jensen K, Ouwehand AC, Jensen SS. Regulation of the IL-10/IL-12 axis in human dendritic cells with probiotic bacteria. FEMS Immunol Med Microbiol. 2011 Oct; 63(1) :93-107.

9. Shida K, Nanno M, Nagata S. Flexible cytokine production by macrophages and T-cells in response to probiotic bacteria: a possible mechanism by which probiotics exert multifunctional immune regulatory activities. Gut Microbes. 2011 Mar-Apr; 2(2) :109-14.

10. Weiss G, Christensen HR, Zeuthen LH, Vogensen FK, Jakobsen M, Frøkiær H. Lactobacilli and bifidobacteria induce differential interferon- $\beta$ profiles in dendritic cells. Cytokine. 2011 Nov; 56(2): 520-30.

11. Haruki Kitazawa, Julio Villena, Susana Avarez, editors. Probiotics: immunobiotics and immunogenic. New York: CRC Press; 2014.

12. de Roock S, van Elk M, van Dijk MEA, Timmerman HM, Rijkers GT, Prakken BJ, et al. Lactic acid bacteria differ in their ability to induce functional regulatory $\mathrm{T}$ cells in humans. Clin Exp Allergy. 2010 Jan; 40(1): 103-10

13. Smelt MJ, de Haan BJ, Bron PA, van Swam I, Meijerink M, Wells JM, et al. L.plantarum, L. salivarius, and $L$. lactis attenuate Th2 responses and increase Treg frequencies in healthy mice in a strain dependent manner. PLoS One. 2012; 7(10): e47244. doi: 10.1371.

14. Liu Y, Fatheree NY, Dingle BM, Tran DQ, Rhoads JM. Lactobacillus reuteri DSM 17938 changes the frequency of Foxp3+ regulatory $\mathrm{T}$ cells in the intestine and mesenteric lymph node in experimental necrotizing enterocolitis. PLoS One. 2013; 8(2): e56547. doi: 10.1371.

15. Yan F, Liu L, Cao H, Moore DJ, Washington MK, Wang B, et al. Neonatal colonization of mice with LGG promotes intestinal development and decreases susceptibility to colitis in adulthood. Mucosal Immunol. 2017 Jan; 10(1): 117-127. doi: 10.1038/mi.2016.43.

16. Galdeano CM, de Moreno de LeBlanc A, Vinderola G, Bonet ME, Perdigón G. Proposed model: mechanisms of immunomodulation induced by probiotic bacteria. Clin Vaccine Immunol. 2007 May; 14 (15): 485-92.

17. Ménard O, Butel MJ, Gaboriau-Routhiau V, WaligoraDupriet AJ. Gnotobiotic mouse immune response induced by Bifidobacterium sp. strains isolated from infants. Appl Environ Microbiol. 2008 Feb; 74(3): 660-6.

18. Verbeek R, Bsibsi M, Plomp A, van Neerven RJ, te Biesebeke R, van Noort JM. Late rather than early responses of human dendritic cells highlight selective induction of cytokines, chemokines and growth factors by probiotic bacteria. Benef Microbes. 2010 Jun; 1(2): 109-19.

19. Lee J, Yang W, Hostetler A, Schultz N, Suckow MA, Stewart KL, et al. Characterization of the anti-inflammatory Lactobacillus reuteri BM36301 and its probiotic benefits on aged mice. BMC Microbiol. 2016 Apr; 16:69. doi: 10.1186/s12866-016-0686-7.

20. House Robert V, Descotes Jacques, editors. Cytokines in Human Health. Immunotoxicology, Pathology, and Therapeutic Applications Immunotoxicology, Pathology, and Therapeutic Applications. New Jersey: Humana Press Inc; 2007.

21. Spivak MYa, Pidgorskyi VS, Lazarenko LM, Shynkarenko LM, Rachkova LT, Olevinska ZM. Lactobacillus and Bifidobacterium influence the indices of immune response of the organism showed on experimental model. Microbiol Biotechnol. 2009; 1: 39-46.

22. Lazarenko L, Babenko L, Shynkarenko-Sichel L, Pidgorskyi V, Mokrozub V, Voronkova O, et al. Antagonistic action of Lactobacilli and Bifidobacteria in relation to Staphylococcus aureus and their influence on the immune response in cases of intravaginal staphylococcosis in mice. Probiotics \& Antimicrob. Prot. 2012; 84: 78-89.

23. Pochard P, Gosset P, Grangette C, Andre C, Tonnel $\mathrm{AB}$, Pestel J, et al. Lactic acid bacteria inhibit TH2 cytokine production by mononuclear cells from allergic patients. $\mathrm{J}$ Allergy Clin Immunol. 2002 Oct; 110(4): 617-23.

24. Li AL, Ma DX, Meng XC. Effect of lactobacilli on Th1/ $\mathrm{Th} 2$ cells balance in primary lymphocytes. Xi Bao Yu Fen Zi Mian Yi Xue Za Zhi. 2011; 27: 389-91.

25. Ren D, Li C, Qin Y, Yin R, Du S, Liu H, et al. Evaluation of immunomodulatory activity of two potential probiotic Lactobacillus strains by in vivo tests. Anaerobe. 2015 Oct; 35(Pt B): 22-7.

26. Xie J, Yu Q, Nie S, Fan S, Xiong T, Xie M. Effects of Lactobacillus plantarum NCU116 on Intestine Mucosal Immunity in Immunosuppressed Mice. J Agric Food Chem. 2015 Dec 30; 63(51): 10914-20.

27. Sharma R, Kapila R, Dass G, Kapila S. Improvement in Th1/Th2 immune homeostasis, antioxidative status and resistance to pathogenic $E$. coli on consumption of probiotic Lactobacillus rhamnosus fermented milk in aging mice. Age (Dordr). 2014; 36(4): 9686.

28. Saliganti V, Kapila R, Kapila S. Consumption of probiotic Lactobacillus rhamnosus (MTCC: 5897) containing fermented milk plays a key role in development of the immune system in newborn mice during the suckling-weaning transition. Microbiol Immunol. 2016 Apr; 60(4): 261-7.

29. López P, GueIMVnde M, Margolles A, Suárez A. Distinct Bifidobacterium strains drive different immune responses in vitro. Int J Food Microbiol. 2010 Mar 31; 138(1-2): 157-65.

30. López P, González-Rodríguez I, GueIMVnde M, Margolles A, Suárez A. Immune response to Bifidobacterium bifidum strains support Treg/Th17 plasticity. PLoS One. 2011; 6(9): e24776. doi: 10.1371.

31. Martín R, Laval L, Chain F, Miquel S, Natividad J, Cherbuy C, et al. Bifidobacterium animalis ssp. lactis CNCM-I2494 Restores Gut Barrier Permeability in Chronically LowGrade Inflamed Mice. Front Microbiol. 2016 May 6; 7:608. doi: 10.3389/fmicb.2016.00608.

Received 26.01.2017 